\title{
Unusual ribulose-1,5-bisphosphate carboxylase/oxygenase genes from a marine manganese-oxidizing bacterium
}

\author{
Ron Caspi, Margo G. Haygood and Bradley M. Tebo \\ Author for correspondence: Bradley M. Tebo. Tcl: +1 619534 5470. Fax: +16195347313. \\ e-mail : btebo@ucsd.edu
}

Marine Biology Research Division and Center for Marine Biotechnology and Biomedicine, Scripps Institution of Oceanography, University of California, San Diego, 9500 Gilman Drive, La Jolla, CA 92093-0202, USA

\begin{abstract}
The Gram-negative bacterium strain SI85-9A1 is a novel marine $\alpha$ proteobacterium that oxidizes manganese(II) to manganese(IV). Initial DNA hybridization screening showed that S185-9A1 possesses a gene similar to cbbL, the gene coding for the large subunit of ribulose-1,5-bisphosphate carboxylase/oxygenase (RubisCO; EC 4.1.1.39). However, no RubisCo enzyme activity was found in cultures of S185-9A1. Genes coding for both large (cbbL) and small (cbbs) subunits of a RubisCo enzyme were identified, isolated and sequenced. When these genes were introduced into an Escherichia coli host strain, ribulose-1,5-bisphosphate-dependent $\mathrm{CO}_{2}$ fixation occurred under control of a lac promoter, indicating that the protein is functional in $E$. coli. Although their function is unknown, this is the first direct evidence for the presence of RubisCO genes in a manganese-oxidizing bacterium. Phylogenetic analysis of the RubisCO genes of strain SI85-9A1 showed that they are divergent, but are more related to those from non-chlorophyte algal chloroplasts than are those from other bacteria. The fact that the Rubisco sequence of strain SI85-9A1 is not closely related to any other published RubisCO sequence suggests that the protein may be valuable for studies of the function and evolution of the RubisCo enzyme as well as its activity in the environment.
\end{abstract}

Keywords: ribulose-1,5-bisphosphate carboxylase/oxygenase, RubisCO, manganese oxidation, autotrophy

\section{INTRODUCTION}

Ribulose-1,5-bisphosphate carboxylase (RubisCO; EC 4.1.1.39) is one of two unique enzymes in the CalvinBenson cycle, the most common pathway for autotrophic $\mathrm{CO}_{2}$ fixation in plants and bacteria. Two forms ( $\mathrm{I}$ and II) are known, and form I Rubis $C O$ s have been categorized into four types (Tabita, 1995). These forms and types are based on evolutionary relationships, and also reflect common biochemical features among the groups. Chloroplasts of terrestrial plants and green algae together with cyanobacteria contain RubisCOs that form a related group

Abbreviations: RubisCO, ribulose-1,5-bisphosphate carboxylase/ oxygenase; RuBP, ribulose 1,5-bisphosphate

The GenBank accession numbers for the cbbS and $c b b L$ sequences, and for the 165 rRNA sequence reported in this paper are $L 32182$ and U53824, respectively.
(Type IB), consistent with the accepted notion of the cyanobacterial origin of chloroplasts. Many marine algal chloroplasts (non-chlorophyte algae) contain RubisCOs (Type ID) that are only distantly related to the cyanobacterial type, and are more closely related to other bacterial RubisCOs (Type IC) than to other chloroplasts. The foutth type (IA) is a group of mostly proteobacterial RubisCOs allied with Type IB, although recently a prochlorophyte was found to have a RubisCO that belongs to this group (Shimada et al., 1995).

Manganese (Mn)-oxidizing bacteria have long been suspected of having autotrophic potential, but the existence of Rubis CO genes in these organisms has never been investigated. Such genes may not only provide evidence consistent with the existence of autotrophic Mn oxidation, but may also be useful in understanding the evolution and biochemical function of RubisCO. It was proposed as early as 1913 (Beijerinck, 1913) that the oxidation of reduced $\mathrm{Mn}[\mathrm{Mn}(\mathrm{II})]$ could provide energy for chemo- 
lithoautotrophic gtowth. Although autotrophy supported by Mn oxidation is thermodynamically favourable, there is only one report that clearly demonstrates net carbon fixation by a Mn oxidizer (Kepkay \& Nealson, 1987). Unfortunately, that organism, Pseudomonas sp. strain S-36, does not demonstrate consistent Mn oxidation in our hands. We have screened 45 Mn-oxidizing environmental isolates with probes constructed from $c b b \mathrm{~L}$ (RubisCO large subunit) genes of both an Anabaena sp. and Xantbobacter strain H4-14, with the aim of finding potential autotrophic strains (Tebo \& Haygood, 1989). About $20 \%$ of the isolates hybridized positively, and strain S185-9A1 was selected because of its consistent and reliable $\mathrm{Mn}$ oxidation.

Restriction analysis with two enzymes followed by DNA hybridization suggested that this strain has only one copy of the RubisCO form I genes, and hybridization with a probe derived from the $c b b M$ gene of Rbodospirillum rubrum, which codes for a form II RubisCO, yielded negative results, suggesting that SI85-9A1 has only one copy of RubisCO genes in the genome.

Strain SI85-9A1 was isolated in 1985 from Saanich Inlet, a stratified fjord on the west coast of Canada. The fjord is anoxic below $\sim 130 \mathrm{~m}$ for about six months every year, resulting in an $\mathrm{O}_{2} / \mathrm{H}_{2} \mathrm{~S}$ interface (Tebo \& Emerson, 1985). Microbial catalysis of Mn oxidation has been demonstrated in this basin above the interface, where there is an accumulation of particulate $\mathrm{Mn}$ (Emerson et al., 1982; Tebo et al., 1984). SI85-9A1 was isolated from water collected at $125 \mathrm{~m}$, within the particulate $\mathrm{Mn}$ maximum. When grown on an appropriate seawaterbased medium containing $\operatorname{Mr}(\mathbf{I})$, the bacteria oxidize $\mathrm{Mn}(\mathrm{II})$ and precipitate $\mathrm{Mn}$ (IV) manganates on the cell surface, forming a coat around the cell. It is a Gramnegative rod-shaped bacterium, which, according to its $16 \mathrm{~S}$ rRNA sequence, belongs to the $\alpha$-subdivision of the proteobacteria. It is not closely related to any of the organisms in the Genbank and RDP databases (GenBank accession number U53824; Maidak et al., 1994). SI85-9A1 grows very slowly, with a doubling time of about $1-2 \mathrm{~d}$, depending on the medium. The final population density in liquid cultures depends on the content of organic nutrients in the medium, and can reach high values (more than $10^{9}$ cells $\mathrm{ml}^{-1}$ ) when grown in a tich medium. However, the bacteria also grow with the one-carbon compound formate as the sole organic carbon and energy source. $\mathrm{Mn}$ oxidation occurs only when grown in organic-poor media, and at the onset of the stationary phase of grow th in batch cultures.

The initial probing results suggested that strain SI85-9A1 possesses a gene similar to $c b b L$, but we wete unable to demonstrate in vitro ribulose-1,5-bisphosphate-dependent $\mathrm{CO}_{2}$ fixation activity or autotrophic growth of the organism. We have proceeded by a molecular approach, cloning, sequencing, and expressing the genes, and thus confirming that the RubisCO genes of strain SI85-9A1 do indeed code for a RubisCO enzyme that is functional, and might, under unknown conditions, be expressed to yield a functional protein in the parent organism.

\section{METHODS}

Bacterial strains, media and growth conditions. Strains and plasmids used in this study ate summarized in Table 1. Strain SI85-9A1 was maintained on solid media K (Krumbein, 1971) and $\mathrm{M}$ which consists of artificial sea water (ASW; see below) supplemented with $50 \mathrm{mg}$ yeast extract $\mathrm{l}^{-1}, 50 \mathrm{mg}$ peptone $\mathrm{l}^{-1}$, $20 \mathrm{mM}$ HEPES buffer (pH 7.8), $100 \mu \mathrm{M} \mathrm{MnCl}_{2}, 2 \mathrm{mM} \mathrm{KHCO}_{3}$ and $15 \mathrm{~g}$ Bacto Noble agar (Difco) $\mathrm{l}^{-1}$. ASW is prepared in out laboratory at doubie strength $(2 \times$ ASW) as follows: $24 \cdot 7 \mathrm{~g}$ $\mathrm{MgSO}_{4}, 7 \mathrm{H}_{2} \mathrm{O}, 2.9 \mathrm{~g} \mathrm{CaCl}_{2}, 2 \mathrm{H}_{2} \mathrm{O}, 35 \cdot 1 \mathrm{~g} \mathrm{NaCl}$ and $1.5 \mathrm{~g} \mathrm{KCl}$ are dissolved individually in $250 \mathrm{ml}$ distilled water each and then combined yielding $112 \times$ ASW, which is diluted by $50 \%$ with distilled water and other components in the final medium.

For large scale DNA preparations the cells were grown in seawater complete (SWC) medium (Nealson, 1978) at room temperature for 1 week. For RubisCO activity assays cells were grown at room temperature for 1 week in ] medium [ASW supplemented with $20 \mathrm{mM}$ HEPES buffer ( $\mathrm{pH} 7.8$ ), $1.5 \mathrm{mM}$ $\mathrm{NH}_{4} \mathrm{Cl}, 2 \mathrm{mM} \mathrm{KHCO}, 10 \mathrm{ml}$ vitamin mix (Kepkay, 1985), $73 \mu \mathrm{M} \mathrm{KH}_{2} \mathrm{PO}_{4}$ and $0.1 \mathrm{ml}$ of a stock solution of $3 \mathrm{mg}$ ferrous ammonium citrate ( $\mathrm{ml} \mathrm{ASW})^{-1}$ ] supplemented with $20 \mathrm{mM}$ formate. Escbericbia coli strains were grown at $37^{\circ} \mathrm{C}$ in $\mathrm{LB}$ medium (Sambrook et al., 1989). Thiobacillus neapolitantus cells were grown in TMN-2 medium (Starr et al., 1981) at room temperature.

Probing of environmental isolates. Forty-five strains of Mnoxidizing bacteria isolated from a variety of marine environments were screened with probes constructed from fragments of the $c b b L$ genes from four organisms: a $1.5 \mathrm{~kb} P s t \mathrm{I}-E_{c o} \mathrm{RI}$ fragment of the plasmid pANP1155, which contains a $2.3 \mathrm{~kb}$ PstI fragment of the $c b b L$ gene of Anacystis nidulans 6301 (Shinozaki \& Sugiura, 1983), a $0.95 \mathrm{~kb} \mathrm{HpaI-HindIII} \mathrm{fragment}$ internal to $c b b L$ from the plasmid pAn600, which contains a $17 \mathrm{~kb}$ fragment including the $c b b L$ gene of Anabaena 7120 (Curtis \& Haselkorn, 1983), a $1.4 \mathrm{~kb}$ EcoRI-BglII fragment of the plasmid pRR2119, which contains a $2.4 \mathrm{~kb}$ fragment of the cbbM gene of Rs. rubrum (Somerville \& Somerville, 1984), and a $0.9 \mathrm{~kb}$ Smal-Sall fragment from the plasmid pLL417R, which contains a $1.7 \mathrm{~kb}$ region of the cbbL gene of Xantbobacter sp. strain H4-14 (Lehmicke \& Lidstrom, 1985). Hybridization conditions were adjusted to the highest stringency that would still allow detection of a T. neapolitanus positive control with the Anabaena probe.

Construction of a genomic DNA library and subcloning the RubisCO genes. Strain SI85-9A1 cells are very difficult to lyse. In order to obtain large quantities of high molecular mass DNA we used the following procedure. Cells were grown in 1 i SWC medium without $\mathrm{Mn}$ to stationary phase (in the presence of $\mathrm{Mn}$ the cells become coated with Mn oxides, making them even more difficult to lyse). The cells were spun down and resuspended in $95 \mathrm{ml}$ TE buffer $\mathrm{pH} 8.0$ (50 mM Tris buffer pH 8.0,10 mM EDTA). The suspension was divided into 10 tubes and $200 \mu \mathrm{l}$ lysozyme solution $\left(50 \mathrm{mg} \mathrm{m}^{-1}\right.$ ) was added to each. The cells were stored on ice for $10 \mathrm{~min}$, then $0.5 \mathrm{ml} 10 \%$ $(\mathrm{w} / \mathrm{v}) \mathrm{SDS}$ and $50 \mu \mathrm{l}$ proteinase $\mathrm{K}$ solution $\left(20 \mathrm{mg} \mathrm{ml}^{-1}\right.$ ) were added to each tube and the cells incubated at $37^{\circ} \mathrm{C}$ for a few hours, until clear. The clear lysate was extracted with CTAB (hexadecyltrimethylammonium bromide, Sigma) and chloroform (Ausubel et al., 1987) and the DNA precipitated, dissolved in TE buffer, and purified on a $\mathrm{CsCl}$ density gradient. The DNA was partially digested with the restriction enzyme $\operatorname{Sau} 3 \mathrm{~A}$, and fragments larger than $20 \mathrm{~kb}$ were purified on a sucrose gradient. The size-fractionated DNA was ligated to pMMB33 cosmid arms as described by Frey et al. (1983), and packaged with a Gigapack XI packaging kit (Stratagene). The packaged library 
Table 1. Bacterial strains and plasmids used in this work

\begin{tabular}{|c|c|c|}
\hline Strain or plasmid & Genetic characteristic(s) & Source or reference \\
\hline \multicolumn{3}{|l|}{ Strains } \\
\hline SI85-9A1 & Manganese oxidizer & This study \\
\hline $\begin{array}{l}\text { Tbiobacillus neapolitanus } \\
\text { ATCC } 23638\end{array}$ & Autotroph & Parker \& Prisk (1953) \\
\hline \multicolumn{3}{|l|}{ Eschericbia coli } \\
\hline DH1 & $\sup E 44$ bsdR 17 rec $A 1$ & Hanahan (1983) \\
\hline XL1-Blue & lac $I^{q}$ lac $Z \Delta \mathrm{M} 15$ & Stratagene \\
\hline \multicolumn{3}{|l|}{ Plasmids } \\
\hline pLL417R & Contains the $c b b L$ gene of Xanthobacter strain H4-14 & Lehmicke \& Lidstrom (1985) \\
\hline PANP1155 & Contains the $c b b L$ gene of Anacystis nidulans 6301 & Shinozaki \& Sugiura (1983) \\
\hline pAn600 & Contains the $c b b L$ gene of Anabaena 7120 & Curtis \& Haselkorn (1983) \\
\hline PRR2119 & Contains the $c b b L$ gene of Rbodospirillum rubrum & $\begin{array}{l}\text { Somerville \& Somerville } \\
\text { (1984) }\end{array}$ \\
\hline pMMB33 & IncQ broad host range, $K \mathrm{~m}^{\mathrm{r}} \cos \hat{\lambda}$ & Frey et al. (1983) \\
\hline pMMB33-7 & pMMB33 containing a $29 \mathrm{~kb}$ fragment of SI85-9A1 chromosome & This study \\
\hline pBluescript II KS $-/ \mathrm{SK}-$ & Phagemid, bla lac $\mathrm{Z}^{\mathrm{e}}$ & Stratagene \\
\hline pRC1 & pBluescript containing a Xhol fragment of pMMB33-7 & This study \\
\hline $\mathrm{pRC1R}$ & As pRC1 with the Xbol fragment in the opposite orientation & This study \\
\hline pRC3 & pBluescript containing a PstI fragment of pMMB33-7 & This study \\
\hline $\mathrm{pRC3R}$ & As pRC3 with the PstI fragment in the opposite orientation & This study \\
\hline pRC4 & pBluescript containing a Sa/I fragment of pMMB33-7 & This study \\
\hline PRC10 & pBluescript containing both $c b b L$ and $c b b S$ & This srudy \\
\hline $\mathrm{pRC11}$ & $\begin{array}{l}\text { pBluescript containing both } c b b L \text { and } c b b S \text { fused to the } l a r \\
\text { promoter }\end{array}$ & This study \\
\hline
\end{tabular}

was transduced into E. coli XL1-Blue cells. The resulting library had about 200000 c.f.u, and a mean insert size of $20 \mathrm{~kb}$.

Ten thousand colonies representing the gene libtary were probed by Southern hybridization with the Xanthobacter sp. strain $\mathrm{H} 4-14$ probe described above, and seven positive colonies were isolated. The cosmid of one of them, pMMB33-7, which contained an insert of $\sim 29 \mathrm{~kb}$, was digested with different restriction enzymes and reprobed. Two positive bands were isolated: a $2013 \mathrm{bp} X b o \mathrm{I}$ fragment, which was cloned into XboIdigested pBluescript $\mathrm{KS}$ - in both orientations, resulting in $\mathrm{pRC1}$ and $\mathrm{pRC1R}$, and a 1678 bp Pstl fragment, which was cloned into Pst I-digested pBluescript $\mathrm{KS}$ - resulting in $\mathrm{pRC} 3$ and pRC3R (Fig. 2). A similarly digested chromosomal DNA yielded positive bands of the same size, suggesting that no rearrangement had occurred. Both $\mathrm{pRC1}$ and $\mathrm{pRC} 1 \mathrm{R}$ were subjected to nested deletions, using an Erase a-Base kit (Promega), resulting in plasmids pRC1-1 to pRC1-10 and pRC1R-1 to PRC1R-10, respectively. Since it was found that plasmids $\mathrm{pRC} 1$ and $\mathrm{pRC} 3$ did not contain the whole $c b b L$ gene, a synthetic oligonucleotide was prepared from the sequence at the end of the Pst I fragment (cbbL1), and used to probe pMMB33-7 again. A positive $S a /$ fragment of $2.5 \mathrm{~kb}$ was isolated and cloned into pBluescript $\mathrm{KS}-$, resulting in $\mathrm{pRC4}$. This plasmid contained the rest of the $c b b L$ gene, and also the cbbs gene.

To generate a clone containing the intact $c b b L / c b b S$ region, the Sall fragment of pRC4 was cut and cloned into the $5 \cdot 1 \mathrm{~kb} S a l \mathrm{I}$ fragment from $p R C 3$. The resulting plasmid was named $\mathrm{pRC} 10$. In order to fuse this insert to the lac promoter of pBluescript, the whole insert of $\mathrm{pRC} 10$ was cut by simultaneous digestion with
KpnI and $S_{a c}$ I, which cut outside the insert but within the multiple cloning site of pBluescript, and cloned into a KpnISacI-digested pBiuescript SK-. The resulting plasmid was named $\mathrm{pRC} 11$.

Southern hybridization. DNA probes were either prepared from double-stranded DNA using a Random Primed DNA Labeling kit (Boehringer Mannheim), or oligonucleotides were synthesized by a DNA synthesizer (Applied Biosystems, model 391) and tailed by a DNA Tailing kit (Boehringer Mannheim) using high specific activity ( $>111 \mathrm{TBq} \mathrm{mmol}^{-1}$ ) $\left[\mathrm{\alpha}_{-}{ }^{32} \mathrm{P}\right] \mathrm{dA} \mathrm{TP}$ (ICN Biochemicals). DNA was transferred to membranes using a downward transfer protocol (Koetsier et al., 1993).

165 rRNA sequencing and analysis. Overlapping fragments of the $16 \mathrm{~S}$ rRNA gene were obtained by PCR amplification using standard methods and primers (Lane, 1990). Sequencing was done with an automated DNA sequencer (ABI model 373A) using a PRISM Ready Reaction DyeDeoxy 'Terminator Cycle Sequencing Kit (Applied Biosystems). The sequence was aligned to other sequences using the RDP World Wide Web server (Maidak et al., 1994). Aligned sequences were imported into paup version 3.0 s (Swofford, 1991) and a phylogenetic tree was generated by a heuristic search using 10 replications of random stepwise additions.

RubisCO sequencing and analysis. Sequencing was done either manually or by an automated sequencer. Single-stranded DNA for manual sequencing was obtained from pBluescript phagemids (Stratagene) according to the manufacturer's instructions, and both strands sequenced with Sequenase version 2.0 (United States Biochemicals). Double-stranded DNA for automated sequencing was obtained with Magic Mini 
Prep Columns (Promega). Resulting DNA sequences were analysed and translated by the MacVector Sequence Analysis Software version 3.5 (International Biotechnologies), and translated sequences were analysed by paup. Sequence alignments were performed manually using Microsoft Excel colour macros (Haygood, 1993). Nucleotide sequence identity was calculated using the alignment feature of the MacVector program. Pairs of SI85-9A1 and each of the other taxa were aligned, identical nucleotides were determined, and percentage identity calculated as the number of identical nucleotides divided by the length of the shorter sequence. Phylogenetic trees were generated from aligned amino acid sequences by heuristic searches, using 10 replications of random stepwise additions with the PROTPARS step matrix, and evaluated by bootstrap analysis. The sequence of the Rs. rubrum cbbM gene, which belongs to the Type II group, was used as an outgroup.

The rooted tree diagram was generated by the TreeDraw program (a version of Drawgram and Drawtree by $\mathrm{J}$. Felsenstein, ported to the Macintosh by D. G. Gilbert, Biology Dept, Indiana University, IN, USA) using branch information generated by PAUP. Branch lengths indicate the inferred number of character state changes on each branch.

Sequences of RubisCO genes from other organisms used in this paper were chosen from those for which the sequence is available for both subunits, and so will represent all the major groups of RubisCO. The following sequences were used (GenBank accession numbers are given in parentheses): Alcaligenes eutrophus (M17744)(Andersen \& Caton, 1987), Anacystis nidulans strain 6301 (X03220) (Shinozaki \& Sugiura, 1983; Shinozaki et al., 1983), Chromatium vinosum (D90204) (Kobayashi et al., 1991), Cblamydomonas reinhardtii (X04471, j01399) (Dron et al., 1982; Goldschmidt-Clermont \& Rahire, 1986), Cryptomonas $\Phi$ (X14171, X62349) (Douglas \& Durnford, 1989; Douglas et al., 1990), Cyanidium caldarium strain RK-15 (X55524) (Valentin \& Zetsche, 1990a), Cylindrotbeca sp. strain N1 (M59080) (Hwang \& Tabita, 1991), Ectocarpus silicolosus (X52503) (Valentin \& Zetsche, 1990b), Olisthodiscus luteus (M24288, X61918) (Boczar et al., 1989; Hardison et al., 1992), Porpbyridium aerugineum (X17597) (Valentin \& Zetsche, 1989), Rhodobacter sphacroides (M64624) (Gibson et al., 1991), Rs. rubrum (X00286) (Nargang et al., 1984), Synechococcus sp. strain a-1 (D13539) (Yaguchi et al., 1993), Thiobacillus ferrooxidans (M85061) (Kusano et al., 1991), Xantbobacter flavus (X17252) (Meijer et al., 1991), and Zea mays (Y00322, V00171) (M. Lebrun, G. Waksman \& B. Freyssinet, Genbank submission; McIntosh et al., 1980).

RubisCO assays. These were modified from a previously published assay (Glover \& Morris, 1979). Strain SI85-9A1 cultures were grown for 1 week, $T$. neapolitanus cultures were grown for $3 \mathrm{~d}$, and $E$. coli cultures were grown overnight. In the morning of the experiment two aliquots of $6 \mathrm{ml}$ of each $E$. coli culture were transferred into sterile tubes. One millilitre of JB medium containing $14 \mathrm{mM}$ IPTG was added to one of the aliquots ( $2 \mathrm{mM}$ final concentration), while $1 \mathrm{ml}$ of LB medium without 1PTG was added to the other. The tubes were incubated at $37^{\circ} \mathrm{C}$ for $2 \mathrm{~h}$ to allow expression of genes fused to the lac promoter. Assay mixtures were prepared by filtering two duplicates of each culture onto Whatman GFF filters. The volumes used were $1 \mathrm{ml}$ for $E$. coll cultures, $10 \mathrm{ml}$ for $T$. neapolitonus and $25 \mathrm{ml}$ for strain SI85-9A1. The filters were placed in scintillation vials, $400 \mu \mathrm{l} 10 \%(\mathrm{v} / \mathrm{v})$ Triton X-100 added and the filters incubated for $10 \mathrm{~min}$. An exception was with strain SI85-9A1 cells, when $200 \mu$ lysozyme in TE $(5 \mathrm{mg}$ $\mathrm{ml}^{-1}$ ) were added first, the cells incubated on ice for $10 \mathrm{~min}$, and then $200 \mu \mathrm{l} 20 \%$ Triton X-100 was added and the cells incubated for $2 \mathrm{~h}$ at room temperature. When the assay mixtures wete ready, $0.93 \mathrm{ml}$ reaction buffer $(70 \mathrm{mM}$ Tris $\mathrm{pH} 8,25 \mathrm{mM}$ glutathione, $25 \mathrm{mM} \mathrm{MgCl}_{2}, 40 \mathrm{mM} \mathrm{NaHCO}$, $3.071 \times 10^{5} \mathrm{~Bq}$ $\mathrm{H}^{14} \mathrm{CO}_{3}^{-} \mathrm{ml}^{-1}$ ) was added to each vial and the vials were incubated at room temperature for $10 \mathrm{~min}$ to activate the enzyme. For each sample, $50 \mu \mathrm{l}$ of a solution containing $4 \mathrm{mg}$ tibulose 1,5-bisphosphate (RuBP) $\mathrm{ml}^{-1}$ (dissolved in 1:5-diluted reaction buffer without radiotracer and adjusted to $\mathrm{pH}$ 6) was added to one duplicate $(360 \mu \mathrm{M}$ final concentration), while $50 \mu \mathrm{l}$ of the same buffer without RuBP was added to the second duplicate.

The reactions were allowed to proceed for $1 \mathrm{~h}$ at room temperature, then terminated by adding $3 \mathrm{ml}$ acetic acid/ methanol $(1: 20, v / v)$ and dried at $65^{\circ} \mathrm{C}$ overnight. Total radioactivity was measured by adding $5 \mu$ l of the stock solution to $0.5 \mathrm{ml} \beta$-phenylethylamine, then adding $10 \mathrm{ml}$ Scintillation cocktail (ScintiVerse BD, Fisher Scientific) to all samples and counting for $5 \mathrm{~min}$ in a Beckman LS $6000 \mathrm{TA}$ scintillation counter.

Total protein concentrations. These were determined using the BCA Protein Assay kit (Pierce), according to the manufacturer's instructions. Samples were taken immediately before filtering cells for the RubisCO activity assay, centrifuged and the pellets frozen. The pellets were later resuspended in TE buffer, and $\mathrm{NaOH}$ and SDS were added to $0 \cdot 1 \mathrm{M}$ and $1 \%$, respectively. Strain SI85-9A1 cells were incubated at $55^{\circ} \mathrm{C}$ overnight; $T$. neapolitanus and E. coli cells lysed immediately.

\section{RESULTS}

\section{5 rRNA sequence}

The 16S rRNA sequence analysis placed strain SI85-9A1 within the $\alpha$-subdivision of the proteobacteria. It is not closely related to any known species, but the closest organisms as determined by the Similarity Rank test are members of the rhizobia group, such as Rbizobium ciceri $\left(S_{\mathrm{ab}} 0.763\right)$ and Rhizobium buakuii $\left(S_{\mathrm{ab}} 0.750\right)$ (Fig. 1).

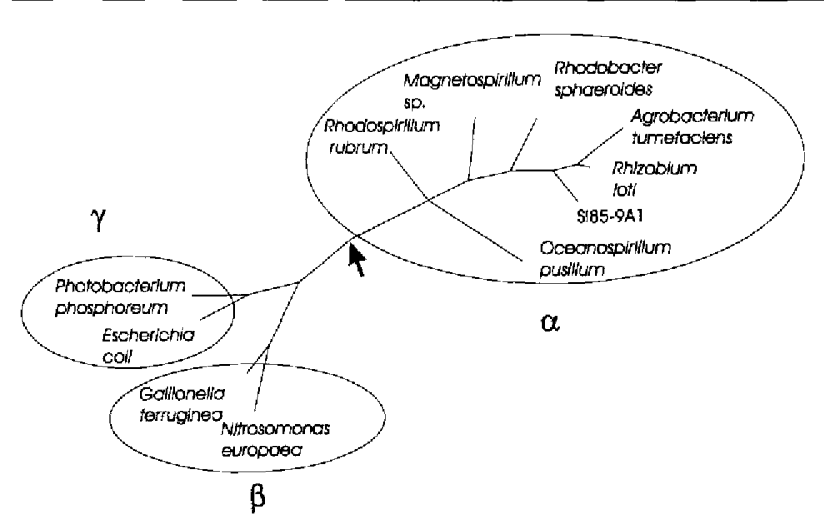

Fig. 1. Relationships among different proteobacteria based on their 165 rRNA sequences, as determined by maximum parsimony (PAUP; Swofford, 1991). Strain SI85-9A1 belongs to the $\alpha$-subdivision of that group. The closest organism to strain SI85-9A1 as determined by the Similarity Rank test is $R h$. ciceri $\left(S_{a b} 0.763\right)$. The arrow indicates position of root (determined with Bacillus subtilis as outgroup). Branch lengths indicate the inferred number of character state changes on each branch. Sequences other than strain SI85-9A1 were obtained from the RDP World Wide Web Server (Maidak et al., 1994). 


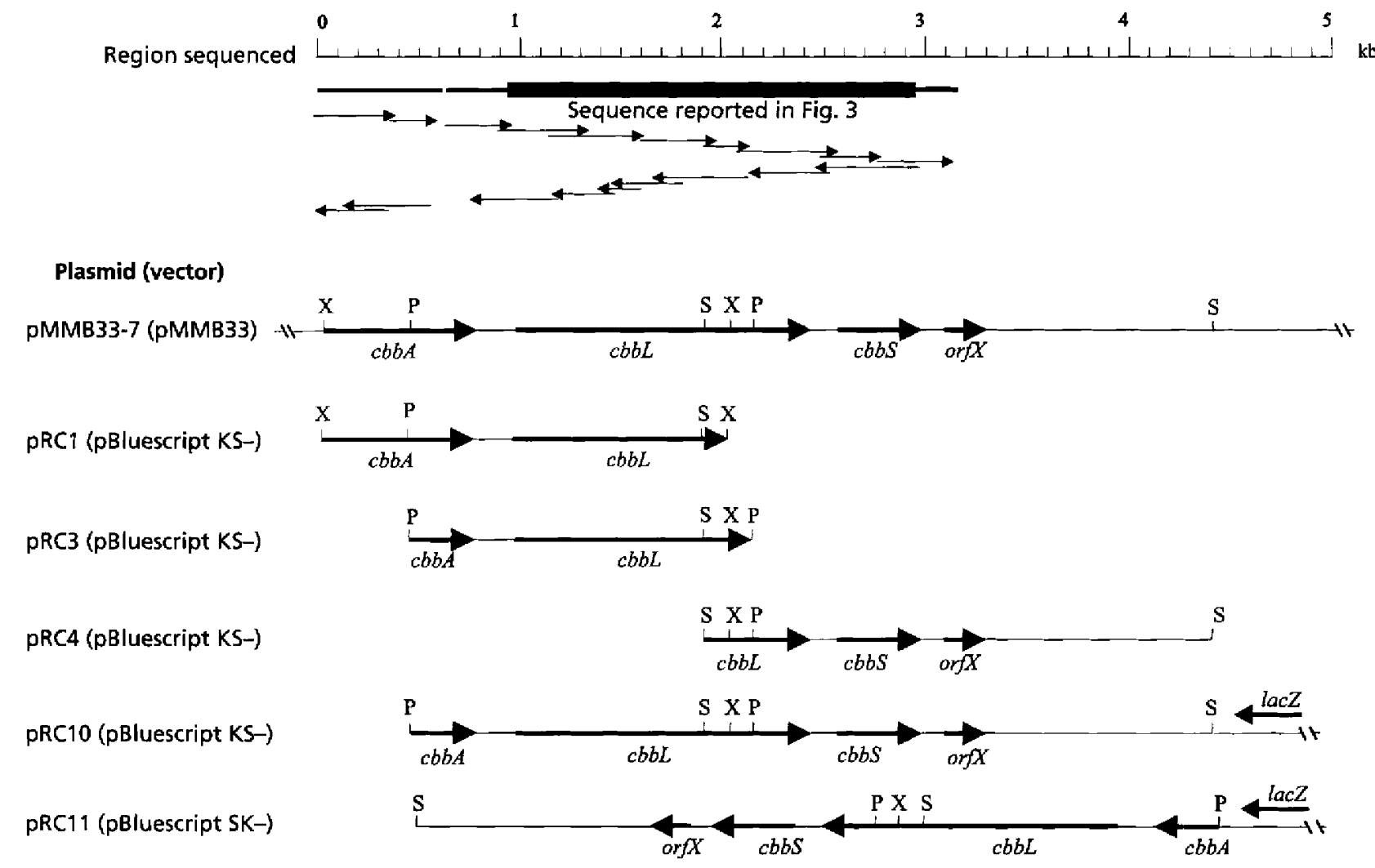

Fig. 2. Restriction maps of $c b b$ regions of plasmid constructs. Restriction fragments were cloned into pBluescript vectors and sequenced using universal and reverse primers or synthetic oligonucleotides. Small arrows show length and direction of sequencing runs. P, Pstl; S, Sall; X, Xhol.

\section{RubisCO sequence}

The region sequenced is shown in Fig. 2. The region containing the $c \dot{b} b L$ and $c \dot{b} b S$ genes was fully sequenced on both strands (Fig. 3). Two additional ORFs were identified from the partial sequence (Fig. 2). The first (partial) ORF contains 762 bp which encode the carboxylterminus 254 amino acids of a putative Calvin cycle aldolase $(c b b A)$. The nucleotide sequence of this gene (not shown) closely resembles ( $75 \%$ identity) that of the $c b b A$ gene of $R b$. sphaeroides (Gibson $e$ t al., 1991). This putative gene ends with a TGA codon and is followed by a noncoding region of $173 \mathrm{bp}$.

The second ORF is $1461 \mathrm{bp}$ long (bases 176-1636), and encodes a 486 amino acid $\mathrm{CbbL}$ subunit. This ORF is preceded by a Shine-Dalgarno sequence (GAAGGAGGA) upstream from $A^{\prime} T G$, the start codon. The $c b b L$. gene is followed by a non-coding region of $114 \mathrm{bp}$ (bases 1637-1750).

The third ORF is $423 \mathrm{bp}$ long (bases 1751-2173), and encodes a 140 amino acid CbbS subunit. This ORF is preceded by a Shine-Dalgarno sequence (GAAGAGGA) located upstream from the ATG statting codon. The $c b b S$ gene is followed by a non-coding region of $129 \mathrm{bp}$.

The fourth (partial) ORF (orf $X$ ) is $100 \mathrm{bp}$ long, and encodes the amino-terminal 33 amino acids (not shown) of an unidentified protein. This ORF is also preceded by a Shine-Dalgatno sequence (GAGGAG).

The DNA sequence of the $c b b$ genes is most similat to RubisCO genes belonging to the Type IC group, namely $\mathrm{R} b$. spbaeroides, $X$. flavus and Al. eutrophus. Table 2 shows the percentage identity of these genes to RubisCO genes from the various groups.

\section{Parsimony analysis}

In order to analyse these genes, we have aligned the amino acid sequences generated by translation of the $a b b L$ and $c b b S$ genes to published sequences from several organisms (Fig. 4). The amino acid sequence generated by translation of strain SI85-9A1 $c b b L$ gene possesses all the amino acids that were found to be implicated in activation and catalysis of the enzyme (Knight $t$ al., 1990). The aligned sequences were analysed by maximum parsimony to generate phylogenetic trees. We generated trees for CbbS, CbbL, and CbbL and CbbS combined, but only the tree constructed for $\mathrm{CbbL}$ is shown (Fig. 5) since the information contained in the CbbS region alone was not sufficient to resolve phylogenetic relationships among some of the organisms, and the result for the combined sequence was similar to that obtained from CbbL alone. The tree was generated using the CbbM protein of $R s$. rubrum (which belongs to the Type II group) as an outgroup. The tree has the following parameters: length 
1 GAGGCCAGCTCCAGCCCGGCCGGTCGCCTGACCGGCCGGTCCCCGCGGCACCGAAACTGACAGATTTMNTTAATGGACGGCGCGACCCCTTTCGCGCC

101 GAAGGGAGACGCTTGTCCGAAATTCGCCGGAAACGGCGCTGCGGACGCAACCGGGATCAACGAAGGAGGACCGTCATGGATCAGGGCTCGCAGACCATCA

$\begin{array}{lllllllllllllllllllllllllllllllllll}G & K & D & R & Y & K & S & G & V & M & E & Y & R & K & M & G & Y & W & E & P & D & Y & E & P & K & E & T & D & V & I & A & C & F\end{array}$

201 AGGGCAAGGACCGCTACAAGTCAGGTGRCATGGATACCGCAAGATGGGCTATTGGGAGCCCGACTACGAACCCAAGGAGACGGACGTCATCGCCTGTTT

$\begin{array}{llllllllllllllllllllllllllllllllllll}R & I & T & P & Q & D & G & V & D & P & I & E & A & A & A & A & V & A & G & E & S & S & T & A & T & W & T & V & V & W & T & D & R\end{array}$

301 CCGGATCACGCCCAGGACGGCGTCGATCCGATCGAGGCGGCGGCGGCGGTGGCCGGCGAATCCTCCACCGCGACATGGACCGTCGTGTGGACCGACCGG

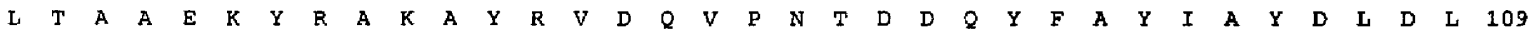

401 CTGACGGCGGCCGAGAAGTACCGGGCCAAGGCCTACCGGGTCGATCAGGTGCCGAACACCGACGACCAGTATTTCGCCTATATCGCCTACGACCTCGACC

$\begin{array}{llllllllllllllllllllllllllllllllllll}F & E & N & G & S & I & A & \text { N } & \text { L } & \text { T } & \text { A } & \text { S } & \text { I } & \text { I } & G & \text { N } & \text { V } & \text { F } & G & \text { F } & \text { K } & \text { P } & \text { L } & \text { K } & \text { G } & \text { L } & \text { R } & \text { L } & \text { E } & \text { D } & M & R & \text { L } & 142\end{array}$

501 TGTTCGAGAACGGCTCGATCGCCAATCTGACGGCGTCGATCATCGGCAATGTCTTCGGCTTCAAGCCGCTGAAGGGCCTGCGGCTGGAGGACATGCGCCT

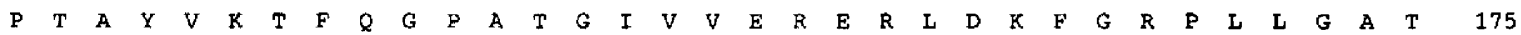

601 GCCGACCGCCTATGTGAAGACCTTCCAGGGGCCGGCGACCGGCATCGTCGTCGAGCGCGAACGCCTCGACAAGTTCGGCCGGCCGCTGCTCGGCGCGACG

$\begin{array}{llllllllllllllllllllllllllllllllllllll}V & K & P & K & \text { L } & G & \text { L } & \text { S } & G & \text { R } & \text { N } & \text { Y } & G & R & \text { V } & \text { V } & \text { Y } & \text { E } & \text { A } & \text { L } & \text { K } & G & G & \text { L } & \text { D } & \text { E } & \text { T } & \text { K } & \text { D } & \text { D } & \text { E } & \text { N } & \text { I } & \text { N } & 209\end{array}$

701 GTGAAGCCCAAGCTCGGCCTGTCGGGCCGCAATTACGGCCGCGICGTCTACGAGGCGCTGAAGGGCGGGCTCGACTTCACCAAGGACGACGAGAACATCA

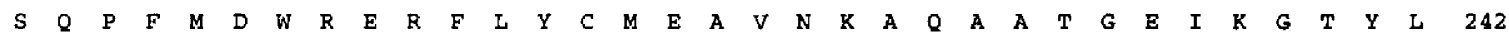

801 ACTCGCAGCCCTTCATGGATTGGCGCGAGCGGTTTCTCTACTGCATGGAGGCGGTGAACAAGGCCCAGGCCGCCACCGGCGAGATCAAGGGAACCTATCT

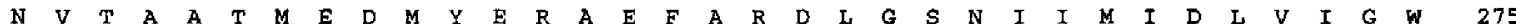

901 CAACGTCACCGCCGCCACCATGGAGGACATGTACGAGCGCGCCGAGTTCGCCAGGGACCTGGGCTCCAACATCATCATGATCGACCTCGTCATCGGCTGG

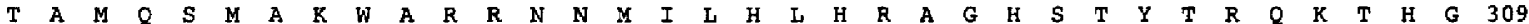

1001 ACCGCCATGCAGTCCATGGCCAAATGGGCGCGOCGCAACAACATGATCCTGCATCTGCACCGGGCGGGCCACTCGACCTATACCCGCCAGAAGACCCACG

$\checkmark$ SalI

101 GCGTGTCGTTCCGGGTGATCGCCAAATGGGCGCGGCTGGCCGGTGTCGACCACATCCATGCCGGCACGGTCGTCGGCAAGCTGGAGGGCGATCCGGCGAC

XhoI

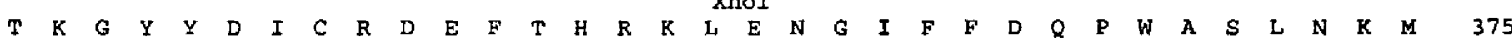

1201 GACCAAGGGCTATTACGACATCTGCCGCGACGAGTTCACCCACCGGAAGCTCGAGAACGGCATCTTCTTCGACCAGCCCTGGGCTTCGCTGAACAAGATG

Pst I

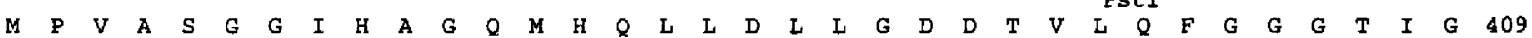

1301 ATGCCGGTGGCCTCGGGCGGCATCCATGCCGGCCAGATGCACCAACTCCTTGATCTTCTCGGCGACGACACCGTGCTGCAGTTCGGCGGCGCACGATCG

$\begin{array}{lllllllllllllllllllllllllllllllllll}\text { H } & P & M & G & \text { I } & \text { A } & \text { A } & G & \text { A } & \text { T } & \text { A } & \text { N } & R & \text { V } & \text { A } & \text { L } & \text { E } & \text { C } & \text { M } & \text { V } & \text { L } & \text { A } & R & \text { N } & \text { E } & G & R & \text { D } & \text { I } & \text { V } & \text { N } & E & G & 442\end{array}$

1401 GCCATCCCATGGGCATCGCCGCCGGCGCGACCGCCAACCGGGTGGGCTGGAATGCATGGTTCTTGCCCGCAACGAGGGCCGGGACATCGTCAATGAGGG

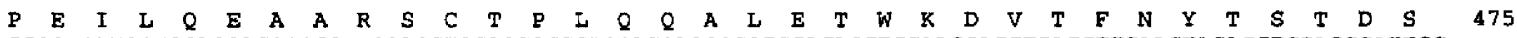

1501 ACCGGAGATCCTGCAGGAGGCGGCAAGGAGCTGCACGCCGCTGCAGCAGGCGCTCGAGACGTGGAAGGACGTGACCTTCAACTACACCTCGACCGATTCC

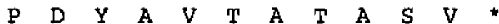

1601 CCCGACTACGCGGTGACGGCGACGGCCTCGGTCTGATCCATCCCGCGTCAGGACGGGGCGAGCCTCCCAACGCCCCGTCCTCCCCATCGATCGAACCCGG

$\begin{array}{llllllllllllllllllllllll}M & R & I & T & Q & G & A & F & S & F & L & P & D & L & T & D & T\end{array}$

1701 CCGGCGCTGCTTGCAAAGGCTGGCGCCGCAACCFGAAGAGGATATCGACCATGCGCATCACCCAAGGGGCATTCTCGTTTCTGCCCGACCTCACCGACAC

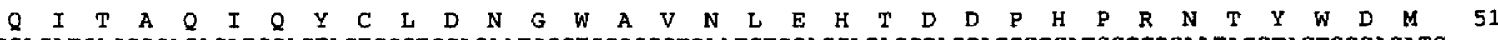

1 BO1 GCAGATCACCGCACAGATCCAGTACTGCCTCGACAATGGCTGGGCGGTGAATCTGGAGCACACCGACGACCCGCATCCGCGCAATACCTACTGGGACATG

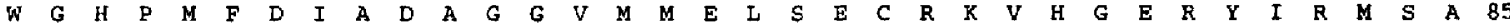

1901 TGGGGGCACCCGATGTTCGACATCGCCGATGCGGGCGGCGTGATGATGGAGTTGTCCGAGTGCCGCAAGGTCCATGGCGAACGCTACATCCGCATGTCGG

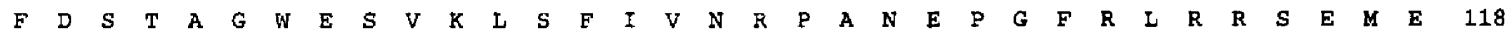

2001 CCTTCGATTCCACGGCCGGCTGGGAGTCGGTGAAGCTGTCCTTCATCGTCAACCGGCCGGCGAACGAGCCGGGCTTCCGGCTGCGCCGCTCGGAAATGGA

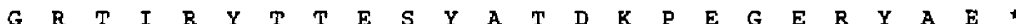

2101 AGGCCGCACTATTCGCTACACGACGGAATCCTACGCCACCGACAAGCCGGAGGGCGAACGCTACGCCGAGTAGCCGTCGGTTGAGCCGCTCCCTCTCCCG

Fig. 3. Nucleotide sequence and deduced amino acid sequence of the $c b b L$ and $c b b S$ region of the insert in pRC10. Predicted amino acid residues are shown above the respective codons. Putative ribosome-binding sites are overlined and stop codons are indicated with asterisks. There is no restriction site at the end of the sequence.

1253, consistency index (CI) $0 \cdot 773$, homoplasy index (HI) $0 \cdot 227$, retention index (RI) 0.746 and rescaled consistency index (RC) 0.576 .

\section{Expression of SI85-9A1 RubisCO in E. coli}

Because we were unable to detect RubisCO enzyme activity in cells of strain SI85-9A1 we thought that the SI85-9A1 RubisCO genes might be nonfunctional. To test this possibility we cloned the genes into an expression system in E. coli and assayed for activity (Table 3 ). The Rubis CO expression experiment included the bacterium $T$. neapolitanus as a positive control, and the E, coli strain $\mathrm{XL1-Blue}$ carrying the plasmid pBluescript as a negative control. The control cells, together with XI.1-Blue cells carrying the plasmids pRC10 and $\mathrm{pRC} 11$, were incubated for $1 \mathrm{~h}$ with and without the lac gene inducer IPTG, and with and without RuBP, in the presence of $\mathrm{H}^{14} \mathrm{CO}_{3}^{-}$. 
Table 2. Nucleotide sequence identity of RubisCO genes from strain $S \mid 85-9 A 1$ with those from other organisms

\begin{tabular}{|c|c|c|c|}
\hline \multirow[t]{2}{*}{ Organism* } & \multirow[t]{2}{*}{ RubisCO group } & \multicolumn{2}{|c|}{ Identity (\%) } \\
\hline & & $c b b L$ & $c b b S$ \\
\hline Rbodobacter sphaeroides & IC & 77 & 72 \\
\hline Xantbobacter flavus & IC & 76 & 65 \\
\hline Alcaligenes entropbus & IC & 75 & 66 \\
\hline Cbromatium winosum & IA & 63 & 43 \\
\hline Porpbyridium aerugineum $\mathrm{cP}$ & ID & 61 & 52 \\
\hline Cryptomonas $\Phi \mathrm{cp}$ & ID & 61 & 48 \\
\hline Anacystis nidulans & IB & 60 & 48 \\
\hline Olisthodiscus luteus cp & ID & 59 & 49 \\
\hline Cyanidium caldarium $\mathrm{cp}$ & ID & 59 & 49 \\
\hline Ectocarpus silicolosus cp & ID & 59 & 50 \\
\hline Thiobacillus ferrooxidans & IA & 59 & 39 \\
\hline Synechocoicus sp. strain a-1 & IB & 59 & 44 \\
\hline Cylindrotheca $\mathrm{sp}$. strain $\mathrm{N} 1 \mathrm{cp}$ & ID & 56 & 52 \\
\hline Cblamydomonas reinhardtii $\mathrm{cp}$ & IB & 50 & 35 \\
\hline Zea mays $\mathrm{cp}$ & IB & 50 & 30 \\
\hline Rhodospirillum rubrum (cbbM) & II & 38 & NA \\
\hline
\end{tabular}

NA, Not applicable.

* cp, chloroplast.

Clone pRC10, which contains the $c b b L / S$ genes in an opposite orientation from the lac promoter of pBluescript, did not show any $\mathrm{RuBP}$-dependent $\mathrm{CO}_{2}$-fixing activity, while clone $\mathrm{pRC11}$, in which the $c b b L / S$ genes are controlled by the lac promoter, demonstrated IPTG- and RuBP-dependent $\mathrm{CO}_{2}$ fixation at a rate of $18 \mathrm{nmol}$ $\mathrm{CO}_{2} \min ^{-1}$ (mg total soluble protein) ${ }^{-1}$ (Table 3). The positive control cells (T. neapolitanus) fixed $\mathrm{CO}_{2}$ in the presence of RuBP at a rate of $51 \cdot 3 \mathrm{nmol} \mathrm{CO}_{2} \mathrm{~min}^{-1}(\mathrm{mg}$ total soluble protein) ${ }^{-1}$. Strain SI85-9A1 showed no RubisCO activity.

\section{DISCUSSION}

The RubisCO genes of strain S185-9A1 are unique, and are not closely related to any other published RubisCO sequences. The most parsimonious tree (Fig. 5) shows that the strain SI85-9A1 genes are about equally closely related to the members of Type IC and Type ID groups. Although the grouping of SI85-9A1 RubisCO with nonchlorophyte algal chloroplast RubisCOs (Type ID) was the most parsimonious with this data set, it was not strongly supported by bootstrapping (the alternative grouped SI85-9A1 at the base of the Type IC group). Nonetheless, all of the analyses support the RubisCO genes of strain SI85-9A1 being closest to Type ID RubisCO genes of non-chlorophyte algal chloroplasts among the bacterial RubisCO genes that have been sequenced to date. This result was obtained by analysing either the sequence of both genes together, or the sequence of $c b b L$ alone.
The Type ID enzymes are the subject of intense current interest because they have a much higher specificity factor (lowet susceptibility to the competing oxygenase reaction) than enzymes of Type IB from terrestrial plants (Tabita, 1995). The bacterial enzymes of 'Type IC have specificity factors in the range of terrestrial plants. The loop 6 region of the large subunit of RubisCO is believed to influence the specificity factor (Read \& Tabita, 1994), and the SI859A1 enzyme shares some amino acids with the Type ID enzymes, some with the Type IC and is unique at other positions. Clearly, the specificity factor and other biochemical properties of the SI85-9A1 RubisCO are important subjects for future investigation.

The issue of autotrophy is particularly interesting in the case of strain S185-9A1 because of its ability to oxidize $\mathrm{Mn}$. For many decades scientists have been debating whether Mn oxidation could provide the necessary energy for autottophic growth (Ali \& Stokes, 1971; Beijerinck, 1913; Ghiorse, 1984; Kepkay \& Nealson, 1987; Nealson et al., 1988; van Veen, 1972). Although we have not yet been able to demonstrate autotrophic growth of strain SI85-9A1, it is apparent that this strain has some of the required genes. 'This, and the fact that strain SI85-9A1 oxidizes Mn only on organic-poor media, suggest that there might be a link between $\mathrm{Mn}$ oxidation and $\mathrm{CO}_{2}$ fixation in this strain.

The sequence data, together with the expression of the genes in an E. coli host, suggest that strain SI85-9A1 might have the capability for synthesizing an active $\mathrm{RubisCO}$ enzyme. It remains unclear, though, under what 
(a)

5185-9A1 A. eutrophus K. sphaeroides U. lutets

C. caldarium

I. ferrooxidans

A. nidulans

mays

SI85.9A

A. eutrophus

R. sphaeroides

O. Luteus

C. caldarium

A nisulans

mays

SI85-9A1

A. eutrophus

$\boldsymbol{k}$. sphaeroides

0. lusews

C. caldarium

I. ferrooxidans

A. nidulans

$\angle$ mays

S185-9A1

A. eutrophus

K. sphaeroides

O. Iuturis

C. caldarium

T. ferrooxidans

A. nidulans

$\angle$ mays

SI85-9A1

A, eutrophus

$\boldsymbol{K}$, sphaeroides

O. Luteus

c. caldarium

T. ferrooxidan

A. nidulans

Z. mays

SI85-9A1

A. eutrophus

R. sphaeroides

0 . luteus

C. caldarium

I. ferrooxidans

A. nidulans

A. mays

(b)

5185-9A1

A. eutrophus

K. sphaeroides

o. iuteus

C. caldarium

1. ferrooxidans

A. midulans

2. mays

S185-9A1

A. eutrophus

K. sphaeroides

O. Inteus

c. caldarium

T. ferrooxidans

A. nidulans

L. mays

SI85-9A1

A. eutrophus

K. sphaeroides

U. inteus

C. caldarium

I. ferrooxidans

A. nidulans

¿n mays
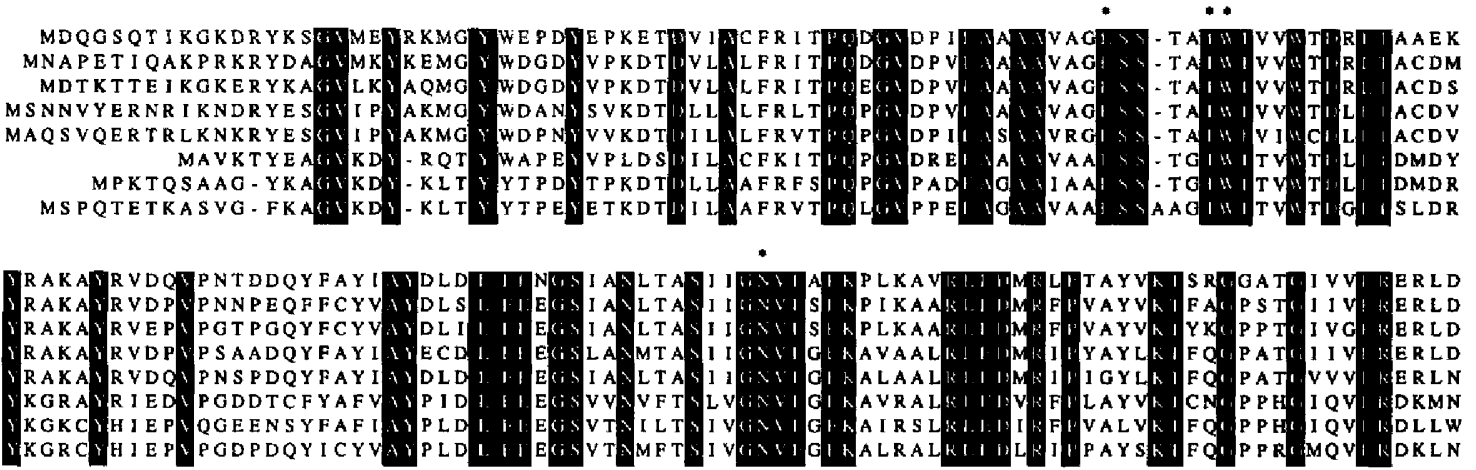

- $*$

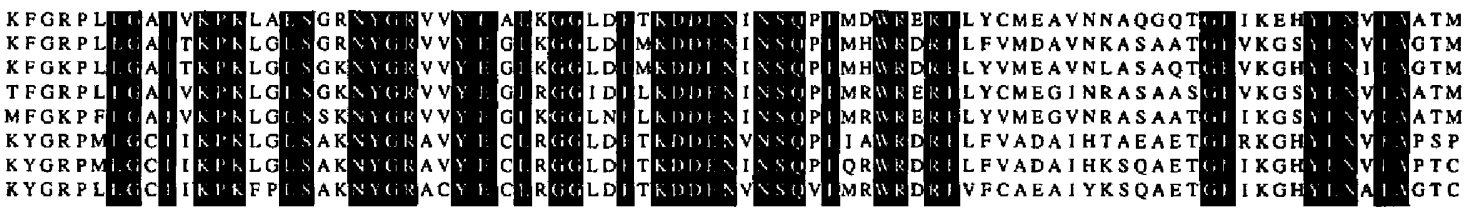

.
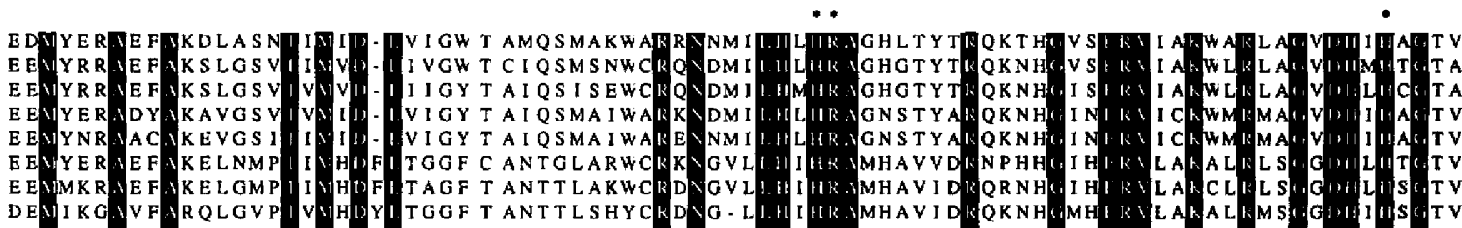

$* *$

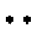

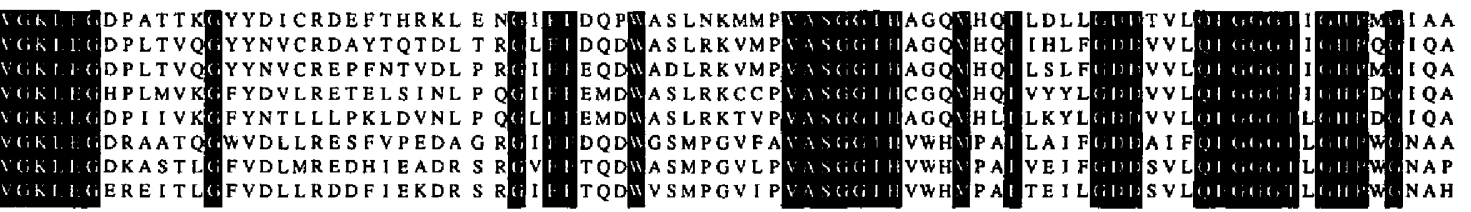

416

417

418

418
408

412

415

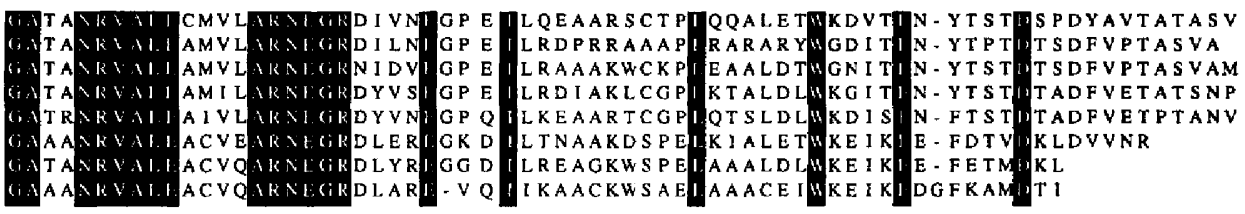

486
487
486
488
488
473
472
475

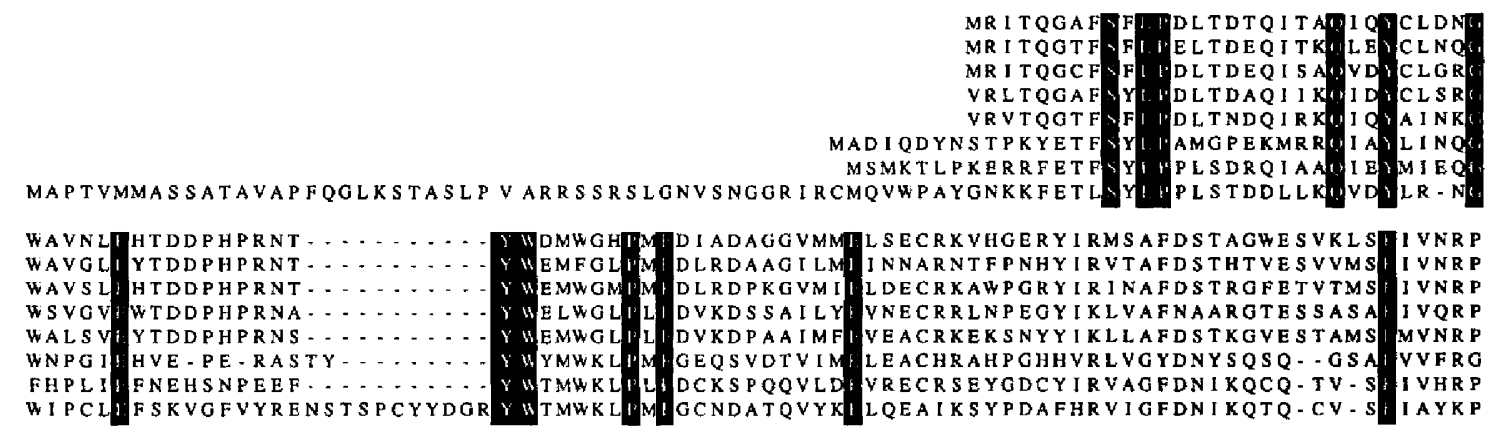

30

30

30

30

38

83

103

103

103

103

109

108

ANEPGFRLRR SEMEGRTIRYTTESYAT DK - PEGERYAE

ADEPGFRLVRQEEPGRTLRYSIESYAV Q AGPK

EVEPSLRMERTEVDGRSIRYTHSIVR

AHEPGFVLRRIESNDRVQRYQIHSYAT

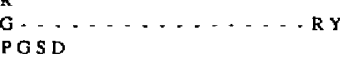
Fig. 4. Amino acid sequence comparison of the Rubisco large (a) and small (b) subunits of different organisms. Identical
residues are shown in white lettering on a black background. Active site residues are labelled with an asterisk (Knight et
al., 1990). 


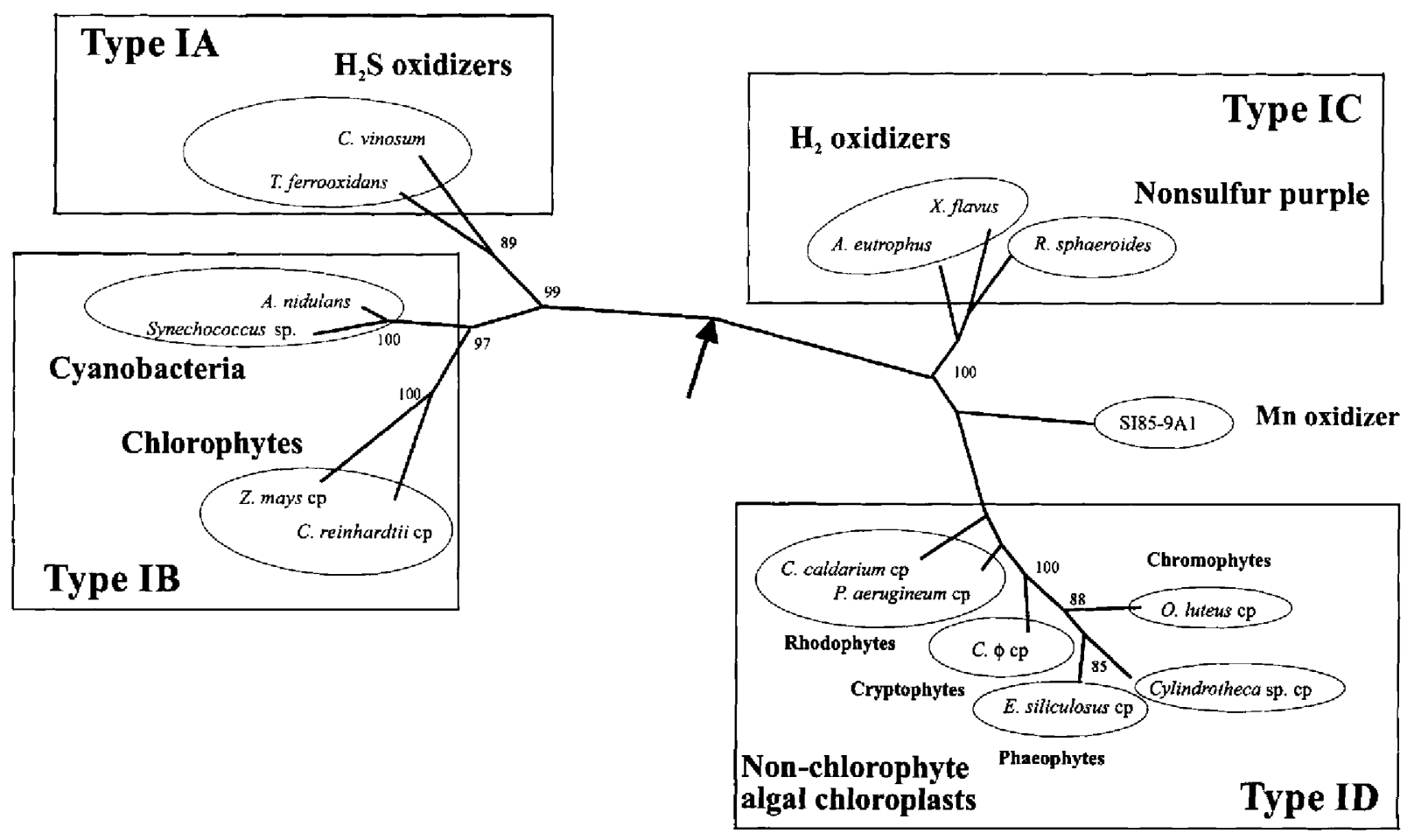

Fig. 5. Relationships among different RubisCo large subunits based on amino acid sequences determined by maximum parsimony (PAUP; Swofford, 1991). The arrow indicates position of root (determined with Rs. rubrum as outgroup). Nodes significantly supported by bootstrap analysis $(>80 \%)$ are labelled with the percentage of bootstrap replicates that supported the node. Branch lengths indicate the inferred number of character state changes on each branch. $c p$, chloroplast.

\section{Table 3. Expression of the RubisCO enzyme}

Results are given as nmol $\mathrm{CO}_{2}$ fixed $\mathrm{min}^{-1}(\mathrm{mg} \text { total soluble protein })^{-1}$. T. neapolitanus was used as a positive control and E. coli XL1-Blue carrying the plasmid $\mathrm{pBluescript} \mathrm{with} \mathrm{no} \mathrm{insert} \mathrm{was} \mathrm{used} \mathrm{as} \mathrm{a}$ negative control.

\begin{tabular}{|c|c|c|c|c|}
\hline & \multicolumn{2}{|c|}{-IPTG } & \multicolumn{2}{|c|}{ + IPTG } \\
\hline & $-\mathbf{R u B P}$ & + RuBP & $-\mathbf{R u B P}$ & $+\mathbf{R u B P}$ \\
\hline pBluescript (no insert; negative control) & $0 \cdot 6$ & $0 \cdot 6$ & $1 \cdot 3$ & $1 \cdot 2$ \\
\hline pRC10 (no lac promoter) & 0.9 & $1 \cdot 2$ & $1 \cdot 0$ & $1 \cdot 2$ \\
\hline $\mathrm{pRC11}$ (lac promoter) & $0 \cdot 6$ & $1 \cdot 4$ & $1 \cdot 1$ & 18 \\
\hline T. neapolitanus (positive control) & $1 \cdot 9$ & $51 \cdot 3$ & $\mathrm{NA}$ & NA \\
\hline SI85-9A1 & $1 \cdot 2$ & $0 \cdot 4$ & NA & NA \\
\hline
\end{tabular}

NA, Not applicable.

circumstances the genes might be expressed. Clone $\mathrm{pRC10}$, in which the genes are not controlled by the lac promoter, did not demonstrate any RubisCO-dependent $\mathrm{CO}_{2}$-fixing activity. However, in most organisms the $r b c L / S$ genes are part of a larger operon that contains other $\mathrm{CO}_{2}$-fixation-related genes $(c b b \mathrm{R}, c b b F, c b b P$ and $c b b A$ ). Since there clearly is a $c b b A$ gene upstream of the $c b b L$ gene in strain SI85-9A1, it is possible that the promoter for this operon is located upstream from the cloned fragment, and is thus missing in clones pRC10 and
pRC11. Alternatively, the promoters might be present, but not recognized by the E. coli transcription machinery. The fact that the Mn-oxidizing strain SI85-9A1 has genes coding for a functional RubisCO enzyme and other carbon fixation genes, suggests that SI85-9A1 is either autotrophic for some energy source, or a heterotrophic descendant of a previously autotrophic organism that lost some of the genes required for autotrophy. In the latter case, the fact that functional RubisCO genes are still present could be explained if the RubisCO genes were 
linked to other essential genes. A similat case has been reported for freshwater Beggiatoa strains (Nelson et al., 1989) that have apparently lost the ability to grow autotrophically, while maintaining the RubisCO genes. Another similar case is that of Tbiobacillus intermedius in which two sets of RubisCO genes are present, coding for both form I and a form II enzymes. However, all attempts to demonstrate the presence of a form II RubisCO enzyme in T. intermedius failed (Stoner \& Shively, 1993). After cloning the genes of $T$. intermedius into $E$. coli, a low level of activity was present, and as in our case, a higher level [32 nmol $\mathrm{CO}_{2}$ fixed $\mathrm{min}^{-1}$ (mg protein) ${ }^{1}$ ] was observed under the control of an external lac promoter.

On the other hand, strain SI85-9A1 may be the first representative of a novel group of organisms that fix $\mathrm{CO}_{2}$ in the environment. A sequence similat to the strain SI85$9 \Lambda 1$ RubisCO was recently obtained from a water column mRNA sample from the Gulf of Mexico at a depth of about $90 \mathrm{~m}$ (Paul \& Pichard, 1996), representing a different ocean basin to that from which strain SI85-9A1 was isolated. The wide distribution and relative abundance of this type of gene implied by the finding, and the fact that the gene was apparently transcribed, underscore the importance of further studies on strain SI85-9A1 and other representatives of this group.

\section{ACKNOWLEDGEMENTS}

We would like to thank Dr D. Bartlett who kindly supplied cosmid pMMB33, D. Edwards and L. Park for the 16S rRNA sequence analysis, and J. H. Paul and S. L. Pichard for allowing us to cite their work prior to publication. This work was supported by an Oceanic Biology grant from the Office of Naval Research (N00014-90J-1097). Initial studies werc also supported by a grant from the National Science Foundation (OCE-8620289). R. Caspi was in part supported by a fellowship from the University of California Toxic Substances Research and Teaching Program.

\section{REFERENCES}

Ali, S. H. \& Stokes, J. L. (1971). Stimulation of hetcrotrophic and autotrophic growth of Sphaerotilus discophorus by manganese ions. Antonie Leewwenboek 37, 519-528.

Andersen, K. \& Caton, J. (1987). Sequence analysis of the Alialigents eutropbus chromosomally encoded ribulose bisphosphate carboxylase large and small subunit genes and their gene products. J Bacteriol 169, 4547 4558.

Ausubel, F. M., Brent, R., Kingston, R. E., Moore, D. D., Seidman, J. G., Smith, J. A. \& Struhl, K. (1987). Current Protocols in Molecular Biology. New York: Wiley.

Beijerinck, M. W. (1913). Oxydation des manganbikatbonates durch bakterien und schimmelpilze. Folia Microbiol 2, 123-134.

Boczar, B. A., Delaney, T. P. \& Cattolico, R. A. (1989). Gene for the ribulose 1,5 bis-phosphate carboxylase small subunit protein of the marine chromophyte Olistbodiscus latews is similar to that of a chemoautotrophic bacterium. Proc Natl Acad $S_{c i}$ USA 86, 4996-4999.

Curtis, S. E. \& Haselkorn, R. (1983). Isolation and sequence of the gene for the large subunit of ribulose-1,5-bisphosphate carboxylase from the cyanobacterium Anabaena 7120. Biocbemistry 80, $1835-1839$.
Douglas, S. E. \& Durnford, D. G. (1989). The small subunit of ribulose-1,5-bisphosphate carboxylase is plastid encoded in the chlorophyll c-containing alga Cryptomonas $\Phi$. Plant Mol Biol 13, $13-20$.

Douglas, S. E., Durnford, D. G. \& Morden, C. W. (1990). Nucleotide sequence of the gene for the large subunit of ribulose-1,5bisphosphate carboxylase/oxygenase from the chlorophyll c-containing alga Cryptomonas $\Phi$ : evidence supporting the polyphyletic origin of plastids. J Pbycol 26, 500-508.

Dron, M., Rahire, M. \& Rochaix, J. D. (1982). Sequence of the chloroplast DNA region of Chlamydomonas reinbardtii containing the gene of the large subunit of ribulose bisphosphate carboxylase and parts of its flanking genes. J Mol Biol 162, 775-793.

Emerson, S., Kalhorn, S., Jacobs, L., Tebo, B. M., Nealson, K. H. \& Rosson, R. A. (1982). Fnvironmental oxidation tate of manganese(II): bacterial catalysis. Gerchim Cosmochim Acta 46, 10731079 .

Frey, J., Bagdasarian, M., Feiss, D., Franklin, F. C. H. \& Deshusses, J. (1983). Stable cosmid vectors that enable the introduction of cloned fragments into a wide range of $\mathrm{Gram}$-negative bacteria. Gene 24, 299-308.

Ghiorse, W. C. (1984). Biology of iron- and manganese-depositing bacteria. Annu Rev Microbiol 38, 515-550.

Gibson, J. L., Falcone, D. L. \& Tabita, F. R. (1991). Nucleotide sequence, transctiptional analysis, and expression of genes encoded within the form $\mathrm{I} \mathrm{CO}_{2}$ fixation operon of Rhodobacter spbaeroides. $J$ Biol Chem 266, 14646-14653.

Glover, H. E. \& Morris, I. (1979). Photosynthetic carboxylating enzymes in marine phytoplankton. Limnol Oceanogr 24, 510-519.

Goldschmidt-Clermont, M. \& Rahire, M. (1986). Sequence, evolution and differential expression of the two genes encoding variant small subunits of ribulose bisphosphate carboxylase/oxygenase in Chlamydomonas reinhardtii. J Mol Biol 191, 421-432.

Hanahan, D. (1983). Studies on transformation of Escherichia coli with plasmids. J Mol Biol 166, 557.

Hardison, L. K., Boczar, B. A., Reynolds, A. E. \& Cattolico, R. A. (1992). A description of the Rubisco large subunit gene and its transcript in Olisthodiscus luteus. Plant Mol Biol 18, 595-599.

Haygood, M. (1993). Spreadsheet macros for coloring sequence alignments. Biotechniques 15, 1084-1089.

Hwang, S. R. \& Tabita, F. R. (1991). Cotranscription, deduced primary stucture, and expression of the chloroplast-encoded $r b c L$ and $r b c S$ genes of the marine diatom Cylindrotbeca sp. strain N1. Biol Cbem 266, 6271-6279.

Kepkay, P. E. (1985). Kinetics of microbial manganese oxidation and trace metal binding in sediments: results from an in situ dialysis technique. Limnol Oceanogr 30, 713726.

Kepkay, P. E. \& Nealson, K. H. (1987). Growth of a manganesc

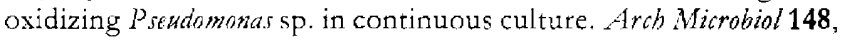
63-67.

Knight, S., Andersson, I. \& Branden, C. I. (1990). Crystallographic analysis of ribulose 1,5-bisphosphate carboxylase from spinach at $2.4 \AA$ resolution - subunit interactions and active sitc. $J \mathrm{Mol}$ Biol $215,113-160$.

Kobayashi, H., Viale, A. M., Takabe, T., Akazawa, T., Wada, K., Shinozaki, K., Kobayashi, K. \& Sugiura, M. (1991). Sequence and expression of genes encoding the large and small subunits of ribulose 1,5-bisphosphate carboxylase/oxygenase from Cbromatium vinosum. Gene 97, 55-62.

Koetsier, P. A., Schorr, J. \& Doerfler, W. (1993). A rapid optimized protocol for downward alkaline Southern blotting of DNA. Biotecbriques 15, 260-262. 
Krumbein, W. E. (1971). Manganese oxidizing fungi and bacteria in recent shelf sediments of the Bay of Biscay and the North Sea. Naturwissenscbaften 58, 56-57.

Kusano, T., Takeshima, T., Inoue, C. \& Sugawara, K. (1991). Evidence for two sets of structural genes coding for ribulose bisphosphate carboxylase in Thiobacillus ferrooxidans. I Bacteriol 73, $7313-7323$.

Lane, D. S. (1990). $16 S$ and $23 S$ rRNA sequencing. In Nucleic Acid Techniques in Bacterial Systematics, pp. 115-148. Edited by E. Stackebrandt \& M. Goodfellow. New York: Wiley.

Lehmicke, L. G. \& Lidstrom, M. E. (1985). Organization of genes necessary for growth of the hydrogen-methanol autotroph Xantbobacter sp. strain H4-14 on hydrogen and carbon dioxide. J Bacteriol 162, 1244-1249.

Melntosh, L., Poulsen, C. \& Bogorad, L. (1980). Chloroplast gene sequence for the large subunit of tibulose bisphosphate carboxylase of maize. Nature 288, 556-566.

Maidak, B. L., Larsen, N., McCaughey, M. J., Overbeek, R., Olsen, G. J., Fogel, K., Blandy, J. \& Woese, C. R. (1994). The Ribosomal Database Project. Nucleic Acids Res 22, 3485-3487.

Meijer, W. G., Arnberg, A. C., Enequist, H. G., Terpstra, P., Lidstrom, M. E. \& Dijkhuizen, L. (1991). Identification and organization of carbon dioxide fixation genes in Xantbobacter favus H4-14, Mol Gen Genet 225, 320-330.

Nargang, F. E., Mcintosh, L. \& Somerville, C. (1984). Nucleotide sequence of the ribulose bisphosphate carboxylase gene from Rhodospirillum rubrum. Mol Gen Genet 193, 220-224.

Nealson, K. H. (1978). Isolation, identification, and manipulation of luminous bacteria. Methods Enzymol 57, 153-166.

Nealson, K. H., Tebo, B. M. \& Rosson, R. A. (1988). Occurrence and mechanisms of microbial oxidation of manganese. Adv Appl Microbiol 33, 279-318.

Nelson, D. C., Williams, C. A., Farah, B. A. \& Shively, J. M. (1989). Occurrence and regulation of Calvin cycle enzymes in nonautotrophic Beggiatoa strains. Arch Microbiol 151, 15-19.

Parker, C. D. \& Prisk, J. (1953). The oxidation of inorganic compounds of sulphur by various sulphur bacteria. J Gen Microbiol 8, 344-364.

Paul, J. H. \& Pichard, S. L. (1996). Molecular approaches to studying natural communities of autotrophs. In Proceedings of the 8 th International Symposium on C-1 Compounds, pp. 301-309. Edited by M. E. Lidstrom \& F. R. Tabita. San Diego: Kluwer.

Read, B. A. \& Tabita, F. R. (1994). High substrate specificity factor ribulose bisphosphate carboxylase/oxygenase from eukaryotic marine algae and properties of recombinant cyanobacterial RubisCO containing 'algal' residue modifications. Arch Biochem Biopbys 312, 210-218.

Sambrook, J., Fritsch, E. F. \& Maniatis, T. (1989). Molecular Cloning: a Laboratory Manual, 2nd edn. Cold Spring Harbor, NY: Cold Spring Harbor Taboratory.

Shimada, A., Kanai, S. \& Maruyama, T. (1995). Partial sequence of ribulose-1,5-bisphosphate carboxylase/oxygenase and the phylogeny of Procbloron and Procblorococcus (Prochlorales). I Mol Evol 40, 671-677.
Shinozaki, K. \& Sugiura, M. (1983). The gene for the small subunit of ribulose-1,5-bisphosphate carboxylase/oxygenase is located close to the gene for the large subunit in the cyanobacterium Anacystis nidulans 6301. Nucleic Acids Res 11, 6957-6964.

Shinozaki, K., Yamada, C., Takahata, N. \& Sugiura, M. (1983). Molecular cloning and sequence analysis of the cyanobacterial gene for the large subunit of ribulose-1,5-bisphosphate carboxylase/ oxygenase. Proc Natl Acad Sci USA 80, 4050-4054.

Somerville, C. R. \& Somerville, S. C. (1984). Cloning and expression of the Rbodospirillum rubrum ribulose bisphosphate carboxylase gene in E. coli. Mol Gen Genet 74, 5463-5467.

Starr, M. P., Stolp, H., Trüper, H. G., Balows, A. \& Schlegel, H. G. (1981). The Prokaryotes. Berlin: Springer-Verlag.

Stoner, M. T. \& Shively, J. M. (1993). Cloning and expression of the D-ribulose-1,5-bisphosphate carboxylase/oxygenase form II gene from Thiobacillus intermedius in Escherichia coli. FEMS Microbiol Lat 107, 287-292.

Swofford, D. L. (1991). PAUP: Pbylogenetic Analysis Using Parsimony, Version 3.0s. Champaign, IL: Illinois Natural History Survey.

Tabita, F. R. (1995). The biochemistry and metabolic regulation of carbon metabolism and $\mathrm{CO}_{2}$ fixation in purple bacteria. In Anoxygenic Photosynthetic Bacteria, pp. 885-914. Edited by R. E. Blankenship, M. T. Madigan \& C. E. Bauer. Dordrecht \& Boston: Kluwer.

Tebo, B. M. \& Emerson, S. (1985). The effect of oxygen tension, $\mathrm{Mn}(\mathrm{II})$ concentration and temperature on the microbially catalyzed $\mathrm{Mn}(\mathrm{II})$ oxidation rate in a marine fjord. Appl Environ Microbiol 50, 1268-1273.

Tebo, B. M. \& Haygood, M. G. (1989). Some manganese(II)oxidizing bacteria have ribulose 1,5-bisphosphate Carboxylase genes. In Abstracts of the 89 th. Annual Meeting of the American Society for Microbiology, vol. 89, p. 233, New Orleans.

Tebo, B. M., Nealson, K. H., Emerson, S. \& Jacobs, L. (1984). Microbial mediation of $\mathrm{Mn}(\mathrm{II})$ and $\mathrm{Co}(\mathrm{II})$ precipitation at the $\mathrm{O}_{2} / \mathrm{H}_{2} \mathrm{~S}$ interfaces in two anoxic fjords. Limmol Oceanogr 29, $1247-1258$.

Valentin, K. \& Zetsche, K. (1989). The genes of both subunits of ribulose-1,5-biphosphate carboxylase constitute an operon on the plastome of a red alga. Curr Genet 16, 203-209.

Valentin, K. \& Zetsche, K. (1990a). Structure of the Rubisco operon from the unicellular red alga Cyanidium caldarium: evidence for a polyphyletic origin of the plastids. Mol Gen Genet 222, 425-430.

Valentin, K. \& Zetsche, K. (1990b). Rubisco genes indicate a close phylogenetic relation between the plastids of Chromophyta and Rhodophyta. Plant Mol Biol 15, 575-584.

van Veen, W. L. (1972). Factors affecting the oxidation of manganese by Sphaerotilus discophorus. Antonie Leeuvenhock 38, 623-627.

Yaguchi, T., Chung, S., Igarashi, Y. \& Kodama, T. (1993). Cloning, sequence and overexpression of the thermophilic cyanobacterium gene for the ribulose-1,5-bisphosphate catboxylase/oxygenase. I Ferment Bioeng 75, 1-8.

Received 29 April 1996; accepted 2 May 1996. 